Dicle Tıp Dergisi / Dicle Medical Journal (2017) 44 (3) :293-298

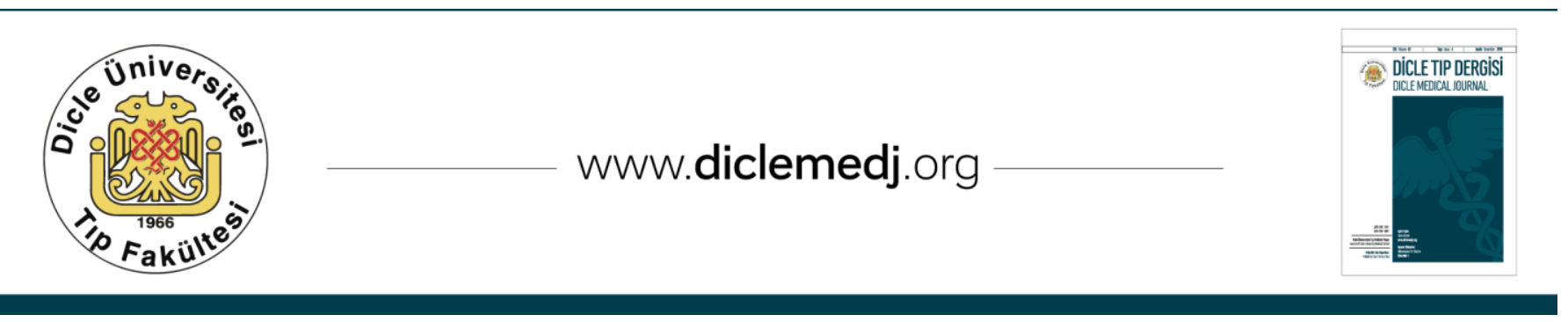

Case Report / Olgu Sunumu

\title{
A newborn with moderate hemophilia A with severe intracranial and extracranial hemorrhage: A case report
}

\author{
Şebnem Kader1, Pınar Gökçe Reis², Mehmet Mutlu³, Yakup Aslan4, \\ Erol Erduran5, Uğur Yazar6
}

1 Karadeniz Technical University Faculty of Medicine, Divisions of Neonatology Trabzon, Turkey ORCID: 0000-0001-7585-4228

2 Karadeniz Technical Univ. Faculty of Medicine, Pediatric Haematology, Departments of Pediatrics Trabzon, Turkey ORCID ID: 0000-0001-9684-3595

3 Karadeniz Technical University Faculty of Medicine, Divisions of Neonatology Trabzon, Turkey ORCID: 0000-0003-3666-3159

4 Karadeniz Technical University Faculty of Medicine, Divisions of Neonatology Trabzon, Turkey ORCID: 0000-0001-9668-9559

5 Karadeniz Technical Univ. Faculty of Medicine, Pediatric Haematology, Departments of Pediatrics Trabzon, Turkey

6 Karadeniz Technical University Faculty of Medicine, Department of Neurosurgery Trabzon, Turkey ORCID: 0000-0003-4749-113x

Received : 27.12.2016; Revised: 10.04.2017 ; Accepted : 27.07.2017

\begin{abstract}
Intracranial hemorrhage among term newborns is a rare clinical condition with high morbidity and mortality. Although major bleeding is relatively uncommon, the incidence of intracranial hemorrhage in hemophilic children is higher during the first few days of life than at any other stage in childhood, which relates to the trauma of delivery. Here, we reported a newborn case diagnosed with moderate hemophilia A, without the presence of a positive family history of hemophilia and presenting with intracranial and extracranial hemorrhage and we aimed to emphasize that the early diagnosis and replacement therapy carries an essential importance.

Keywords: newborn, hemophilia A, intracranial hemorrhage, extracranial hemorrhage.
\end{abstract}

\section{Ağır intrakranial ve ekstrakranial kanaması olan orta hemofili A tanılı bir yenidoğan: Olgu sunumu}

Özet

İntrakranial kanamalar term yenidoğanlarda nadir görülen, morbidite ve mortalitesi yüksek bir klinik tablodur. Majör kanamalar nispeten nadir olmasına rağmen, hemofilik çocuklarda yaşamın ilk birkaç gününde doğum travmasına bağlı gelişebilecek intrakranial kanama insidansı, çocukluğun herhangi bir evresine göre daha yüksektir.

Burada, ailesinde hemofili öyküsü bulunmayan, intrakranial ve ekstrakranial hemoraji ile başvurup orta derecede hemofili A tanısı konan bir yenidoğan olgusunu sunmayı ve erken teşhis ve replasman tedavisinin hayati bir öneme sahip olduğunu vurgulamayı amaçladık.

Anahtar kelimeler: Yenidoğan, hemofili A, intrakranial hemoraji, ekstrakranial hemoraji

DOI: $10.5798 /$ dicletip.339025

Yazıșma Adresi / Correspondence: Sebnem Kader, Department of Pediatrics, Division of Neonatology, Karadeniz Technical University Faculty of Medicine Trabzon, Turkey.e-mail: sebnem_kader@yahoo.com 


\section{INTRODUCTION}

Hemophilia is one of the common hereditary bleeding disorder that may lead to severe lifethreatening bleeding. Most hemophilic patients experience no problem during the neonatal period, but bleeding including intracranial hemorrhage leading to severe mortality and morbidity may rarely be observed during this period. Early diagnosis is very important in terms of prognosis in these cases. However, the diagnosis is usually delayed due to confusion of clinical signs of intracranial bleeding with other conditions in the newborn period, absence of family history in $30 \%$ of cases and the lack of information about the mother is a carrier of hemophilia ${ }^{1}$.

In this case report, we presented a newborn diagnosed with extracranial hemorrhage (ECH) on the first postnatal day was then referred to our tertiary neonatal intensive care unit on the 7th day of life in an intubated status because of respiratory arrest due to intracranial hemorrhage (ICH) and was diagnosed with moderate hemophilia A with no familial history. We aimed to emphasize the fact that moderate hemophilia could also rarely lead to intracranial hemorrhage in term newborns and early diagnosis and replacement treatment were of vital importance.

\section{CASE}

A male baby who was born to a 25 -year-old G1P1 mother at 38 weeks gestation via normal vaginal delivery without any interference was administered vitamin $\mathrm{K}$ at birth. On the first day of life, he was detected with computerized brain tomography with the complaints of swelling on the scalp at the left frontoparietal area and diagnosed with cephal hematoma. However the patient's coagulation parameters were not evaluated. Phototherapy was administered to the patient because of jaundice on the $6^{\text {th }}$ postnatal day. In the follow-up, feeding problems and pathological apnea developed on the $7^{\text {th }}$ postnatal day and a seizure in the form of pedaling occurred so a control computerized brain tomography was performed. The patient was found to have intracranial hemorrhage so he was referred to our tertiary neonatal intensive care unit for further investigation and treatment. The family history revealed no history of bleeding disorders. There was no consanguinity.

On physical examination general condition was poor and he had no spontaneous ventilation. Jaundice and pallor were present. The apical heart rate was 176/minute and blood pressure was found to be $58 / 36 \mathrm{mmHg}$. On the left frontoparietal region of the scalp $5 \times 5 \mathrm{~cm}$ swelling was detected (Fig-1). On neurological examination, hypotonia, a bulging fontanelle, decrease in response to light reflex and bilateral miosis were found.

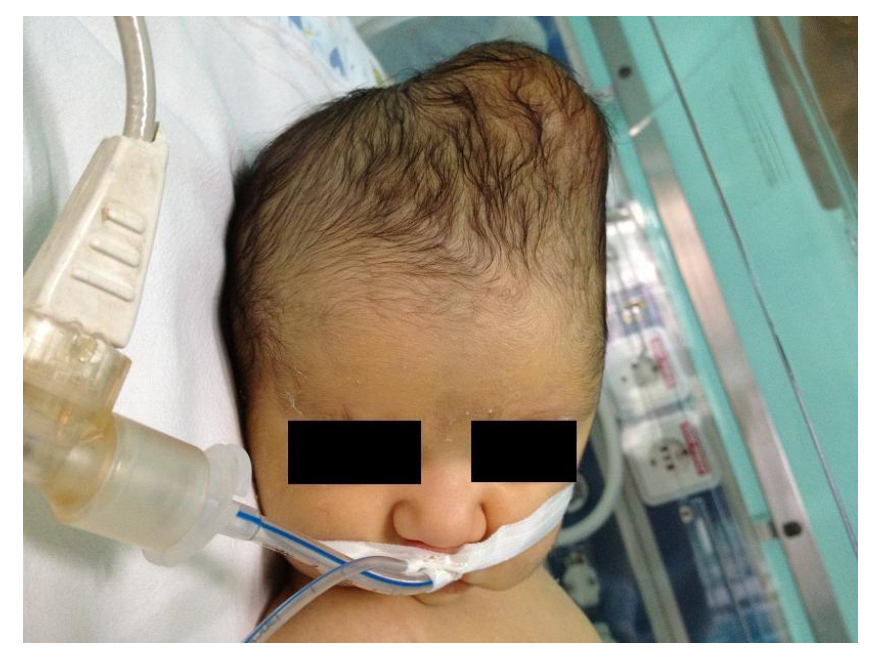

Fig. 1. Patient's phenotypic view. Note the swelling on the left frontoparietal region of the scalp

Laboratory test results were as follows: hemoglobin: $10.5 \mathrm{gr} / \mathrm{dl}$, hematocrit: $30 \%$, platelets: $320.000 / \mathrm{mm} 3$, prothrombin time (PT): 14 s, INR: 1.34, activated partial thromboplastin time (aPTT): 71s, C-reactive protein: $0.27 \mathrm{mg} / \mathrm{dl}(0-0.5)$, and total/direct bilirubin $18.9 / 0.81 \mathrm{mg} / \mathrm{dl}$. On the peripheral smear, clustered platelets were observed. The bleeding time was within the normal limits. 
Since spontaneous ventilation was not present, mechanical ventilation support was given to the patient. Phototherapy was started and phenytoin was given as an antiepileptic treatment. A follow-up brain CT was performed because of the rapid progression of the clinical status with the recommendation of the neurosurgery division. A subgaleal hematoma with a dimension of $53 \times 20 \mathrm{~mm}$ at the left frontoparietal region (Fig-2 A), parenchymal hematomas with a dimension of $6 \times 5 \mathrm{~mm}$ in the medulla oblongata, $8 \times 7 \mathrm{~mm}$ in the left part of the mesencephalon and $34 \times 28 \mathrm{~mm}$ in the right cerebellar hemisphere were observed (Fig-2 B). Obliteration in the basal cisterns and fourth ventricle, shifting of the right cerebellar hemisphere to the left side, subdural hemorrhage in the posterior interhemispheric fissure with a dimension of six $\mathrm{mm}$, hydrocephalic dilatation in the third and lateral ventricles were reported (Fig-2 B). As the patient had a prolonged aPTT, factor levels (Factor VIII, IX, XI) and von Willebrand factor (vWF) levels were studied. Afterwards, he was given fresh frozen plasma support and then he was transfused with erythrocyte suspension because of anemia. Follow-up coagulation parameters were found to be as follows: PT: 14.3 s, INR: 1.24 , aPTT: 44 s. An intervention to evacuate the hematoma was performed by the department of neurosurgery. The Factor VIII (FVIII) level was found to be $4.1 \%$. The patient was considered to have moderate hemophilia A and concentrated factor treatment was administered for two weeks with a target factor level of $100 \%$. The levels of other factors were found to be within the normal limits. The level of his mother's FVIII was found to be $136 \%$. He was extubated on the postoperative 3rd day and was discharged on the $18^{\text {th }}$ day of hospitalization as his symptoms improved. The patient was started to be followed up neurologically and hematologically.

\section{DISCUSSION}

Intracranial hemorrhage may be caused by birth trauma, maternal chorioamnionitis, prematurity, perinatal asphyxia, prolonged neonatal resuscitation, respiratory distress, hypotension, hypoxia, acidosis, hypercapnia, breech presentation, hepatic failure and congenital or acquired coagulation disorders in the neonatal period ${ }^{2}$. The incidence of ICH ranges between $2.2 \%$ and $7.5 \%$ in all patients with a diagnosis of hemophilia, whereas it has been reported to range between $1 \%$ and $4 \%$ in the neonatal period ${ }^{3,4}$.
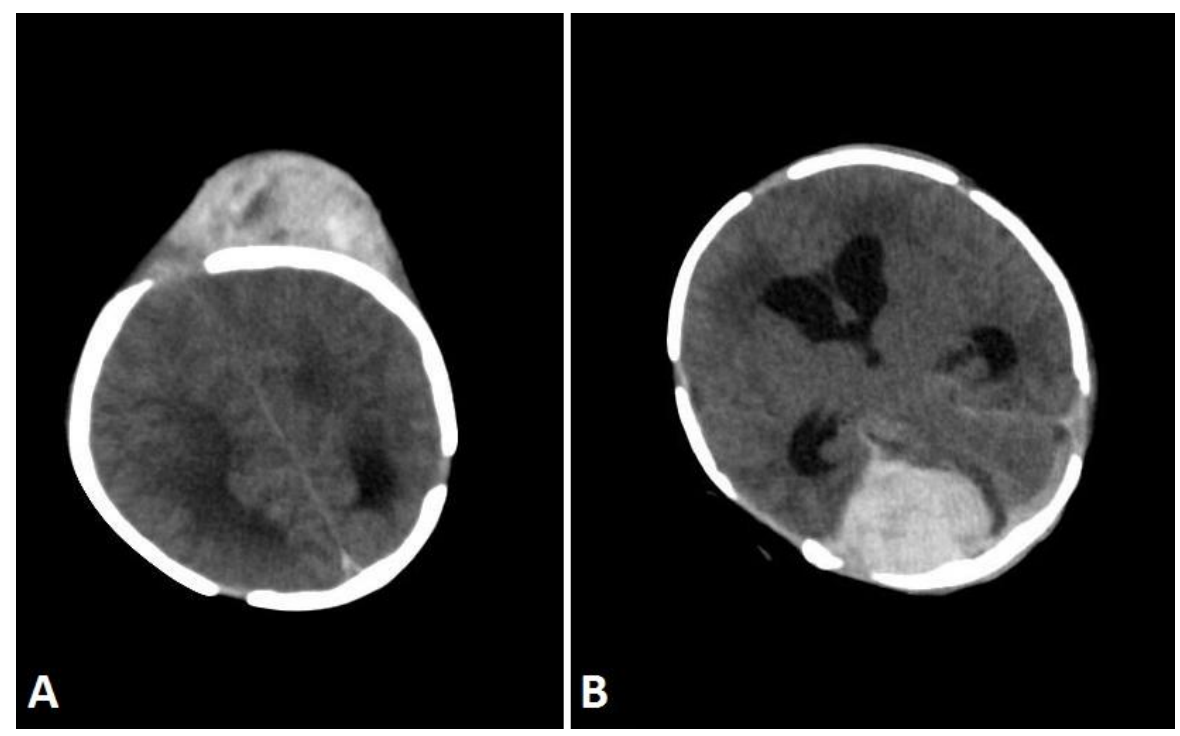

Fig. 2. A: subgaleal hematoma with a dimension at the left frontoparietal region. B: Parenchymal hematomas with a dimension in the right cerebellar hemisphere and shifting of the right cerebellar hemisphere to the left side 
Hemophilia A is a congenital hemorrhagic disease with $\mathrm{X}$-linked recessive inheritance that occurs as a result of deficiency of Factor VIII. The gene of Factor FVIII is localized on the long arm of the $10^{\text {th }}$ chromosome ${ }^{5}$. The combined incidence of hemophilia $\mathrm{A}$ and $\mathrm{B}$ has been reported to be 1 in 5000 live male births. Rarely, hemophilia A is also observed in female children ${ }^{6} .80 \%$ of patients have hemophilia A and $60-70 \%$ of these have severe hemophilia $A$ and $32 \%$ have moderate and mild hemophilia $\mathrm{A}^{7,8}$. In approximately $1 / 3$ of cases, the disease may occur with spontaneous de novo mutations without a familial history. Absence of familial history and the fact that our patient was the first member on the family diagnosed with hemophilia suggested us that the condition occurred as a result of de novo mutation.

In laboratory investigations of patients with hemophilia, the platelet count, bleeding time, prothrombin time and thrombin time are normal, while the activated partial thromboplastin time (aPTT) is prolonged. Factor levels should be measured to determine the type and severity of hemophilia. The severity of the hemorrhage is related with the degree of deficiency of Factor VIII. The patients with a factor activity $<1 \%$ show a clinical form of "severe hemophilia", patients with a factor activity of 1-5\% show a clinical form of "moderate hemophilia" and patients with a factor activity of $>5 \%$ show a clinical form of "mildhemophilia"9. In approximately $2 / 3$ of patients with hemophilia $\mathrm{A}$ have the factor activity $<1 \%$. Our patient was considered to have moderate hemophilia, since the level of Factor VIII was measured to be $4.1 \%$ which was between $1 \%$ and $5 \%$.

Intracranial hemorrhage is defined as bleeding into the cranial cavity; ECH is defined as bleeding outside the cranial cavity including subgaleal hematoma and cephalhematoma 4 . While subgaleal hemorrhage means bleeding between the cranial bones and aponeurosis, cephalhematoma

bleeding ${ }^{10}$.

means

subperiosteal

Bleeding findings related with hemophilia in the neonatal period may be in the form of blood leakage from the umbilical cord, hemorrhage in the scalp, extracranial hemorrhage including cephalhematoma and subgaleal hematoma, subcutaneous hemorrhage, intramuscular hemorrhage, bleeding after circumcision, persistent bleeding after taking blood samples via a peripheral vein, mucosal bleeding, rarely surrenal bleeding, hematoma in the liver or arterial pseudoaneurysm following the taking of arterial blood sample $4,11,12$. Our patient had subgaleal hematoma, subdural hemorrhage and multiple intraparenchymal bleeding foci.

It is important to evaluate patients with subgaleal hematoma or cephalhematoma in terms of hemorrhagic diathesis. Brain CT was performed to our patient because of swelling on the scalp on the first postnatal day, but he was not investigated in terms of hemorrhagic diathesis. In a study in which newborns with subgaleal hemorrhage were evaluated, the mortality rate related with hemorrhagic shock due to subgaleal hemorrhage in all newborns with or without a diagnosis of hemophilia was reported to be $22.8 \%{ }^{13}$. Ljung et al. ${ }^{14}$ reported the rate of $\mathrm{ECH}$ to be $10.2 \%$ and the rate of $\mathrm{ICH}$ to be $3.4 \%$ in hemophilic newborns. In another study in which hemophilic newborns with ICH and $\mathrm{ECH}$ were evaluated, it was found that $62.8 \%$ of 35 patients with a diagnosis of hemophilia A had a severe clinical form of hemophilia, $28.7 \%$ had a moderate clinical form of hemophilia and $8.5 \%$ had a mild clinical form of hemophilia 4 . In a multi-center study, it was reported that ICH developed in $4 \%$ of 744 hemophilic newborns and it was stated that, in $40 \%$ of these patients ICH occurred in the first week of life ${ }^{15}$. In our patient who had a moderate clinical form of hemophilia, ICH and ECH occurred in the first week of life in accordance with the literature. 
Identification of the cause of neonatal hyperbilirubinemia is useful for avoiding severe hyperbilirubinemia. Hyperbilirubinemia can be caused by increased bilirubin production, decreased bilirubin clearance and increased enterohepatic circulation. Sequestration of blood within a closed space can lead to bilirubin production due to increased red blood cell breakdown. In our patient, hyperbilirubinemia requiring phototherapy was observed due to ICH and ECH.

The diagnosis is made after bleeding in patients with a newly diagnosed hemophilia that occurs as a result of de novo mutation. In patients with $\mathrm{ICH}$, findings including anemia, pallor, facial paralysis, respiratory and pulse irregularities, vomiting, lethargy, hypotension, a bulging fontanelle, pupilla changes, apnea, convulsion and coma may be observed. Convulsion is mostly observed in the acute phase of ICH. In the long-term follow-up of patients with hemophilia, severe neurological sequelae including decrease in the intellectual capacity, speech disorders, porencephaly, psychomotor and statomotor retardation, visual disorders and cerebral palsy have been reported ${ }^{4,15-17}$. It has been reported that the most efficient factor in determining the severity of these sequelaes is the age at which ICH develops and hemophilic patients with ICH in the neonatal period have a poorer neurological prognosis compared to the children in the other age groups ${ }^{15}$. Our patient also presented with clinical findings including pallor, convulsion, hypotension, respiratory arrest and a bulging fontanelle. He had both ICH and ECH and was started to be followed up in terms of sequelae which might occur in the long-term following the surgical operation performed.

In patients in whom hemophilia is considered, fresh frozen plasma should be given in such a way that the level of Factor VIII is $100 \%$ until the results of factor levels are obtained (1 unit/kg fresh frozen plasma increases the level of Factor VIII by 2\%). After the diagnosis is certain, recombinant factor concentrates or factor concentrates originating from highly pure plasma are recommended ${ }^{18}$. Currently, recombinant factor FVIII concentrates are the most commonly used treatment. In patients with intracranial hemorrhage, factor replacement should be performed in such a way to increase the factor level to $100 \%$ and the treatment should be continued for 2-6 weeks ${ }^{19}$. Hemorrhage may need to be evacuated by surgical intervention in some cases as in our case ${ }^{19}$. In our patient who developed intracranial hemorrhage, coagulation parameters were normalized by fresh frozen plasma and afterwards the hematoma was evacuated by surgical intervention by the neurosurgery department. After the diagnosis is certain, concentrated factor replacement was performed and continued for 2 weeks to increase the factor level to $100 \%$. Our patient was followed up with brain imaging. Genetic counseling was recommended to the family of our patient for future pregnancies and it was advised to protect the baby from traumas. Our patient is still being followed up in our hematology and neurology outpatient clinics.

Conclusively, in this case report, we aimed to emphasize the importance of evaluation of coagulation parameters in newborns with bleeding, the fact that the hemophilia disease can rarely lead to severe intracranial hemorrhage and early diagnosis and replacement treatment are of vital importance.

Declaration of Conflicting Interests: The authors declare that they have no conflict of interest.

Financial Disclosure: No financial support was received 


\section{REFERENCES}

1. Lawn RM. The molecular genetics of hemophilia: blood clotting factors VIII and IX. Cell. 1985; 42:405-6.

2. Levene MI, Fawer CL, Lamont RF. Risk factors in the development of intraventricular haemorrhage in the preterm neonate. Arch Dis Child. 1982 ;57:410-7.

3. Eyster ME, Gill FM, Blatt PM, et al. Central nervous system bleeding in hemophiliacs. Blood. 1978; 51: 1179-88.

4. Kulkarni R, Lusher JM. Intracranial and extracranial hemorrhages in newborns with hemophilia: a review of the literature. J Pediatr Hematol Oncol.1999;21:289-95.

5. Green PM, Montandon AJ, Bentley DR, Giannelli F. Genetics and molecular biology of haemophilias $\mathrm{A}$ and B. Blood Coagul Fibrinolysis.1991;2:539-65.

6. Byams VR, Kouides PA, Kulkarni R, et al. Surveillance of female patients with inherited bleeding disorders in United States Haemophilia Treatment Centres. Haemophilia. 2011;17:6-13.

7. Walker I, Pai M, Akabutu J, et al. The Canadian Hemophilia Registry as the basis for a national system for monitoring the use of factor concentrates. Transfusion. 1995; 35:548-51.

8. Geraghty S, Dunkley T, Harrington C, et al. Practice patterns in haemophilia A therapy -global progress towards optimal care. Haemophilia. 2006; 12:75-81.

9. White GC, 2nd, Rosendaal F, et al. Definitions in hemophilia. Recommendation of the scientific subcommittee on factor VIII and factor IX of the scientific and standardization committee of the International Society on Thrombosis and Haemostasis. Thromb Haemost. 2001; 85:560.
10. Chadwick LM, Pemberton PJ, Kurinczuk JJ. Neonatal subgaleal haematoma: associated risk factors, complications and outcome. J Paediatr Child Health.1996; 32:228-32.

11. Le Pommelet C, Durand P, Laurian Y, Devictor D. Haemophilia A: two cases showing unusual features at birth. Haemophilia. 1998;4: 122-5.

12. Johnson-Robbins LA, Porter JC, Horgan MJ. Splenic rupture in a newborn with hemophilia A: case report and review of the literature. Clin Pediatr. 1999; 38:1179.

13. Plauche WC. Subgaleal hematoma. A complication of instrumental delivery. JAMA. 1980; 244:1597-8.

14. Ljung R, Lindgren AC, Petrini P, Tengborn L. Normal vaginal delivery is to be recommended for haemophilia carrier gravidae. Acta Paediatr. 1994; 83:609-11.

15. Klinge J, Auberger K, Auerswald G, et al. Prevalence and outcome of intracranial haemorrhage in haemophiliacs--a survey of the paediatric group of the German Society of Thrombosis and Haemostasis (GTH). Eur J Pediatr. 1999; 158:162-5.

16. Patiroglu T, Ozdemir MA, Unal E, et al. Intracranial hemorrhage in children with congenital factor deficiencies. Childs Nerv Syst. 2011; 27:1963-6.

17. Bladen $M$, Khair K, Liesner R, Main E. Long-term consequences of intracranial haemorrhage in children with haemophilia. Haemophilia. 2009; 15:184-92.

18. Baehner RL, Strauss HS. Hemophilia in the first year of life. N Engl J Med.1966; 275:524-8.

19. Kulkarni $\mathrm{R}$, Lusher J. Perinatal management of newborns with haemophilia. Br J Haematol. 2001; 112:264-74. 